\title{
Ectoparasites and Pathogens of Kuhl's Pipistrelle Pipistrellus kuhlii (Kuhl, 1817) (Chiroptera: Vespertilionidae): Our Own and Published Data Review
}

\author{
M. V. Orlova ${ }^{a, b, *}$, D. G. Smirnov ${ }^{c, * *}$, V. P. Vekhnik ${ }^{d, * * *}$, \\ A. M. Lukyanenko ${ }^{c, * *}$, and A. V. Zabashta ${ }^{e, * * *}$ \\ ${ }^{a}$ Tyumen State University, Tyumen, 625003 Russia \\ ${ }^{b}$ Tomsk National Research State University, Tomsk, 634050 Russia \\ ${ }^{c}$ Penza State University, Penza, 440026 Russia \\ ${ }^{d}$ Sprygin State Natural Biosphere Reserve, Zhigulevsk, 445362 Russia \\ ${ }^{e}$ Rostov-on-Don Anti-Plague Scientific Research Institute, Rostov-on-Don, 344002 Russia \\ *e-mail: masha_orlova@mail.ru \\ **e-mail: eptesicus@mail.ru \\ ***e-mail:vekhnik@mail.ru \\ ****e-mail: zabashta68@mail.ru
}

Received December 26, 2019; revised July 21, 2020; accepted August 20, 2020

\begin{abstract}
Here we report the results of our own survey and literary published data on the ectoparasite fauna and pathogens of the alien bat species, the Kuhl's pipistrelle Pipistrellus kuhlii (Kuhl, 1817) (Chiroptera: Vespertilionidae). This bat is a host of 36 species of parasitic mites, ticks and insects (including accidental findings) and 13 species of pathogens (protozoa, bacteria, viruses). The flea Ischnopsyllus variabilis is re-corded on this host for the first time. We have found that outside of the host ancestral range, the core of the bat parasite fauna is significantly different due to the loss of host species-specific ectoparasites. Particularly, in Russia, only 6 species of parasitic arthropods have been recorded for Kuhl's pipistrelle and all of them are host genus-specific. At the same time, the features of ecology and occasional finds of extrinsic parasites allow to suggest that $P$. kuhlii has wide contacts with animals which are the reservoirs of zoonotic infec-tions, that in combination with the fact of isolation of several pathogens from this species (including two coronaviruses) points to a possible medical importance of Kuhl's pipistrelle.
\end{abstract}

Keywords: Kuhl's pipistrelle, Pipistrellus kuhlii, bat ectoparasites, Steatonyssus periblepharus, Ischnopsyllus variabilis, Carios vespertilionis

DOI: $10.1134 /$ S2075111720040104

\section{INTRODUCTION}

The Kuhl's pipistrelle or Mediterranean Pipistrellus kuhlii (Kuhl 1817), originating from the south (Strelkov and Il'in, 1990; Vernier and Bogdanowicz, 1999), originally preferred open plain arid and semiarid landscapes of the Mediterranean, North Africa, Near East, and Kashmir (Strelkov et al., 1985). Progressive spread of this species was reported over the last several decades in Europe (Il'in, 2000; Strelkov, 2004; Bogdanowicz, 2004; Sachanowicz et al., 2006). This contributed to the expansion of the total area of the range by a factor of five (Ancillotto et al., 2016). A pronounced tendency toward synanthropy, high adaptability to various climatic conditions, and general global warming induced its rapid dispersal in the northerly and easterly directions. From the direction of the south of Central and Eastern European, the spe- cies expansion northward was first reported as early as the 1980 s, when P. kuhlii was recorded from the north of the Alps in Switzerland, southern Germany, Austria, and Hungary (Haffner et al., 1991; Feher, 1995; Bauer, 1996; Meschede et al., 1998; Fiedler et al., 1999; Spitzenberger and Bauer, 2001). Currently, the species has reached the latitude of $50^{\circ}$ and was reported from Slovakia (Ceeluch and Ševčík, 2006; Danko, 2007), the Czech Republic (Reiter et al., 2007), and Poland (Sachnowicz et al., 2006). Additionally, the active dispersal was recorded in Ukraine (Kedrov and Shurshak, 1999; Godlevsky et al., 2000; Poluda and Zagorodnyuk, 2001; Gavris' and Kotserzhinskaya, 2002; Zagorodnyuk and Reznik, 2007; Gashchak et al., 2009; Godlevs'ka, 2015), Belarus (Demyanchik, 2013; Shpak and Larchenko, 2016), and Central Asia (Strelkov, 2004). 
Prior to the mid-20th century, finds of $P$. kuhlii were known to be rare from the regions neighboring Russia, specifically, a few settlements in Transcaucasia and Central Asia and in Crimea (Kuzyakin, 1950; Strelkov, 1963). In the east of European Russia, the starting point of this species expansion was southeastern Transcaucasia, where a rapid buildup of its population level was observed in the 1940s-1950s (Vereshchagin, 1959). The first finds were made in Rostovon-Don in 1975 (Yarmysh and Kazakov, 1977), in Grozny and Abrau-Dyurso in Krasnodar territory in 1977 (Yarmysh et al., 1980), and North Ossetia in 1978 (Komarov and Kuchiev, 1982). In the Volga region, P. kuhlii was first discovered in 1980 in the vicinity of Lake Baskunchak in Astrakhan region $\left(48^{\circ} \mathrm{N}\right)$ (Lindeman and Subbotin, 1983), where the typical plain species was able to arrive exclusively from the south, while migrating along the western coast of the Caspian Sea (Strelkov et al., 1985). Taking into account, however, its subsequent spread northward, it is not implausible that the species could have found its way to the region much earlier. By 1985, its finds had already been reported from the north of Volgograd region, where it reached $50^{\circ} \mathrm{N}$ (Strelkov et al., 1985). P. kuhlii was detected in Saratov region at $51^{\circ}$ latitude in 1988 (Strelkov and Il'in, 1990) and reported from $52^{\circ} \mathrm{N}$ as early as 1995 (Zav'yalov and Shlyakhtin, 1999). In 1997, the animals were already found by us in Samara, whereas soon after, its habitat was identified in the cities of Novokuibyshevsk and Tolyatti (Smirnov and Vekhnik, 2011). The species was found at Samara Bend and in Penza and Ul'yanovsk regions in the early 2000s (Il'in et al., 2006; Zolina et al., 2007; Smirnov et al., 2007; Shepelev et al., 2008; Smirnov and Vekhnik, 2011), as well as in the Republic of Mordovia (Artaev and Smirnov, 2016). About the same time, it was detected in Voronezh (Smirnov and Vekhnik, 2011), Tambov (Lada, 2010), Bryansk (Sitnikova et al., 2009), and Moscow (Kruskop and Kozhurina, personal communication) regions. Prior to 1990 in the Transvolga, finds of $P$. kuhlii were limited to occasional spots located easterly up to the Bolshoy Uzen River within the Volga-Ural interfluve (Strelkov and Il'in, 1990). Further eastward, the species was found at the end of the 20th century strictly in the proximity to the Ural River Delta (Shaimardanov, 2001). Attempts made in the 1990s and in the early 2000s with intent to find it in the floodplain of the lower and middle reaches of the Ural River yielded no result; but in 2008, P. kuhlii was detected at a number of points in Orenburg and Chelyabinsk regions nevertheless (Davygora et al., 2009). The northmost find was made in Udmurtiya (Izhevsk) in winter 1991, but the animal was probably transported there accidently by vehicle from the south (Kapitonov and Grigor'ev, 1995).

Despite the spotlight recently put on the Kuhl's pipistrelle (Smirnov and Vekhnik, 2011; Godlevs'ka, 2015; Shpak and Larchenko, 2016; Ancillotto et al., 2016; Sachnowicz et al., 2017), the parasitic fauna and pathogens associated with the species are considered in scattered fragmentary communications from various (primarily, African, Asian, and South European) parts of the range. As for Russia, five or six species of ectoparasites were described earlier. No information, in actual fact, is available from Western Europe. From the epidemiological perspective, bats are, however, known to be a huge reservoir of zoonotic infections. The literature mentions at least 250 virus agents alone, including infectious agents of dangerous diseases, such as rabies, Ebola fever, SARS, MERS, and COVID-2019 isolated from microbats or otherwise detected in their body (Schountz, 2013; Moratelli and Calisher, 2015), while, in addition, many of their ectoparasites are involved in circulation of agents of different nature (Orlova and Kononova, 2018). As already been mentioned, the Kuhl's pipistrelle demonstrates active expansion across the territory of Russia and, therefore, may possibly transport the temporal ectoparasites over a considerable distance, thus causing a number of diseases to spread further.

\section{MATERIALS AND METHODS}

Bats were captured using the trapping nets during the period of 2006-2019; the age and sex were determined in each individual and the reproductive state (pregnancy and lactation) was determined in females (Racey, 2009). Thirty-nine individuals of the studied species were captured in Astrakhan region by D.G. Smirnov, V.P. Vekhnik, and A.M. Luk'yanenko in the following localities: village of Ivanchug $\left(46^{\circ} 04^{\prime} \mathrm{N}, 47^{\circ} 59^{\prime} \mathrm{E}\right.$; May 22, 2018, four specimens); Astrakhan Nature Reserve, Damchikskii site $\left(45^{\circ} 47^{\prime}\right.$ N, $47^{\circ} 53^{\prime}$ E; May 23, 2018, 17 specimens); Astrakhan Nature Reserve, Obzhorovskii cordon (guard station) ( $46^{\circ} 18^{\prime} \mathrm{N}, 48^{\circ} 59^{\prime} \mathrm{E}$; August 27 and 28, 2019; 18 specimens). In Dagestan, pipistrelles were captured by Smirnov and Vekhnik in the village of Kochubei $\left(44^{\circ} 24^{\prime}\right.$ N, $46^{\circ} 32^{\prime}$ E; April 24, 2019; five individuals examined), in the outskirts of Khasavyurt on the Aktash River $\left(43^{\circ} 17^{\prime} \mathrm{N}, 46^{\circ} 38^{\prime} \mathrm{E}\right.$; May 20, 2019; three specimens), and in the Agrakhanskii Sanctuary of the Dagestan State Natural Reserve $\left(43^{\circ} 48^{\prime} \mathrm{N}, 47^{\circ} 31^{\prime} \mathrm{E}\right.$; May 23, 2019; three specimens). One animal of this species was captured by Smirnov in the village of Novospasskoe, Ul'yanovsk region $\left(53^{\circ} 08^{\prime}\right.$ N, $43^{\circ} 45^{\prime}$ E; August 17, 2006). In Rostov region, one individual was trapped by Zabashta in the outskirts of Rostov-on-Don $\left(47^{\circ} 29^{\prime}\right.$ N, $39^{\circ} 56^{\prime} \mathrm{E}$; July 20, 2019). Thus, a total of 52 individuals of $P$. kuhlii were examined in eight localities of the Russian south; after the examination and collection of ectoparasites, all bats were released in the wild.

Ectoparasites were sampled using tweezers and needle and fixed in 70\% ethanol. Permanent preparations were made using Faure-Berlese mounting medium according to standard technique (Whitaker, 1988); parasites were identified by M.V. Orlova using standard keys and other taxonomic publications (Hopkins 
Table 1. Distribution of the Kuhl's pipistrelle across the localities ( $n$ is the number of examined hosts; first line is the absolute number; second line is $\mathrm{MI}$; and third line is $P, \%$ )

\begin{tabular}{|c|c|c|c|c|c|c|c|c|c|}
\hline \multirow[t]{3}{*}{ Locality } & \multicolumn{3}{|c|}{ Astrakhan region } & \multicolumn{3}{|c|}{ Dagestan } & \multirow{3}{*}{$\begin{array}{l}\text { Rostov } \\
\text { region }\end{array}$} & \multirow{3}{*}{$\begin{array}{c}\text { Ul'yanovsk } \\
\text { region }\end{array}$} & \multirow{3}{*}{ Total } \\
\hline & \multicolumn{2}{|c|}{ Astrakhan Nature Reserve } & \multirow[b]{2}{*}{$\begin{array}{c}\text { Ivanchug } \\
\text { village }\end{array}$} & \multirow[b]{2}{*}{  } & \multirow{2}{*}{ 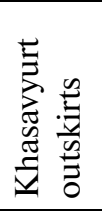 } & \multirow{2}{*}{ 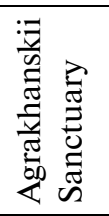 } & & & \\
\hline & $\begin{array}{l}\text { Obzhorovskii } \\
\text { cordon }\end{array}$ & $\begin{array}{c}\text { Damchikskii } \\
\text { site }\end{array}$ & & & & & & & \\
\hline $\begin{array}{c}\text { Species } \\
\text { of parasite }\end{array}$ & $n=18$ & $n=17$ & $n=4$ & $n=5$ & $n=3$ & $n=3$ & $n=1$ & $n=1$ & $n=52$ \\
\hline $\begin{array}{l}\text { Steatonyssus } \\
\text { periblepharus }\end{array}$ & $\begin{array}{r}10 \\
1 \\
56\end{array}$ & - & - & $\begin{array}{c}18 \\
3.6 \\
100\end{array}$ & $\begin{array}{c}7 \\
3.5 \\
67\end{array}$ & $\begin{array}{c}10 \\
3.3 \\
100\end{array}$ & 7 & - & $\begin{array}{c}52 \\
2.5 \\
40\end{array}$ \\
\hline $\begin{array}{l}\text { Carios } \\
\text { vespertilionis }\end{array}$ & $\begin{array}{r}4 \\
2 \\
11\end{array}$ & - & - & - & - & - & - & - & $\begin{array}{l}4 \\
2 \\
4\end{array}$ \\
\hline $\begin{array}{l}\text { Ischnopsyllus } \\
\text { octactenus }\end{array}$ & $\begin{array}{r}5 \\
1 \\
28\end{array}$ & $\begin{array}{r}3 \\
1 \\
18\end{array}$ & $\begin{array}{c}5 \\
1.3 \\
100\end{array}$ & $\begin{array}{r}2 \\
2 \\
20\end{array}$ & - & $\begin{array}{r}1 \\
1 \\
33\end{array}$ & - & - & $\begin{array}{l}16 \\
1.14 \\
27\end{array}$ \\
\hline $\begin{array}{l}\text { Ischnopsyllus } \\
\text { variabilis }\end{array}$ & - & - & - & - & - & - & - & 1 & $\begin{array}{l}1 \\
1 \\
2\end{array}$ \\
\hline Total & $\begin{array}{c}19 \\
2.1 \\
50\end{array}$ & $\begin{array}{r}3 \\
1 \\
18\end{array}$ & $\begin{array}{c}5 \\
1.3 \\
100\end{array}$ & $\begin{array}{r}20 \\
4 \\
100\end{array}$ & $\begin{array}{c}7 \\
3.5 \\
67\end{array}$ & $\begin{array}{c}11 \\
3.7 \\
100\end{array}$ & 7 & 1 & $\begin{array}{c}73 \\
2.6 \\
54\end{array}$ \\
\hline
\end{tabular}

and Rothschild, 1956; Filippova, 1966; Orlova et al., 2016). The core of the parasitic fauna was assessed on the basis of the parameters proposed by Balashov (2009). Host infestation parameters are presented using the standard parasitology indices, such as MI (mean intensity), which is the mean number of parasites per infested host, and P (prevalence), which is percentage of infested individuals.

\section{RESULTS}

There were 73 specimens of four ectoparasite species (in Acari and insects) collected from the examined individuals of $P$. kuhlii (Table 1).

\section{Acari: Gamasina: Macronyssidae}

Steatonyssus periblepharus Kolenati, 1858: 4 우, 6 N1 (Astrakhansk Nature Reserve, Obzhorovskii cordon, August 27 and 28, 2019); 13 우, 5 N1 (Dagestan, Kochubei village, April 24, 2019); 3 우, 4 N1 (Dagestan, Khasavyurt outskirts, May 20, 2019); 9 우 (including one with intrauterine egg); N1 (Dagestan, Agrakhanskii Sanctuary, May 23, 2019); đ^, 6 N1 (Rostov region, Platov Airport, July 20, 2019).
Acari: Parasitiformes: Argasidae

Carios vespertilionis Latreille, 1796: 4 L (Astrakhan Nature Reserve, Obzhorovskii cordon, August 27 and 28, 2019).

\section{Insecta: Siphonaptera: Ischnopsyllidae}

Ischnopsyllus octactenus (Kolenati, 1856): 5 우 (Astrakhan region, Ivanchug, May 22, 2018); 2 우, o (Astrakhan Nature Reserve, Damchikskii site, May 23, 2018); 4 우, đo (Astrakhan Nature Reserve, Obzhorovskii cordon, August 27 and 28, 2019); $\subsetneq$ and ${ }^{\star}$ (Dagestan, Kochubei village, April 24, 2019); ᄋ (Dagestan, Agrakhanskii Sanctuary, May 23, 2019).

Ischnopsyllus variabilis (Wagner, 1898): ᄋ (Ul'yanovsk region, Novospasskoe village, August 17, 2006).

\section{DISCUSSION}

Our samples feature the dominant number of S. periblepharus (52 out of 73 specimens (in other words, nearly three-fourth of the collected parasites) found in five out of eight inspected localities. The intensity of their infestation of bats is relatively low (MI not exceeding 3.6); the proportion of infested 


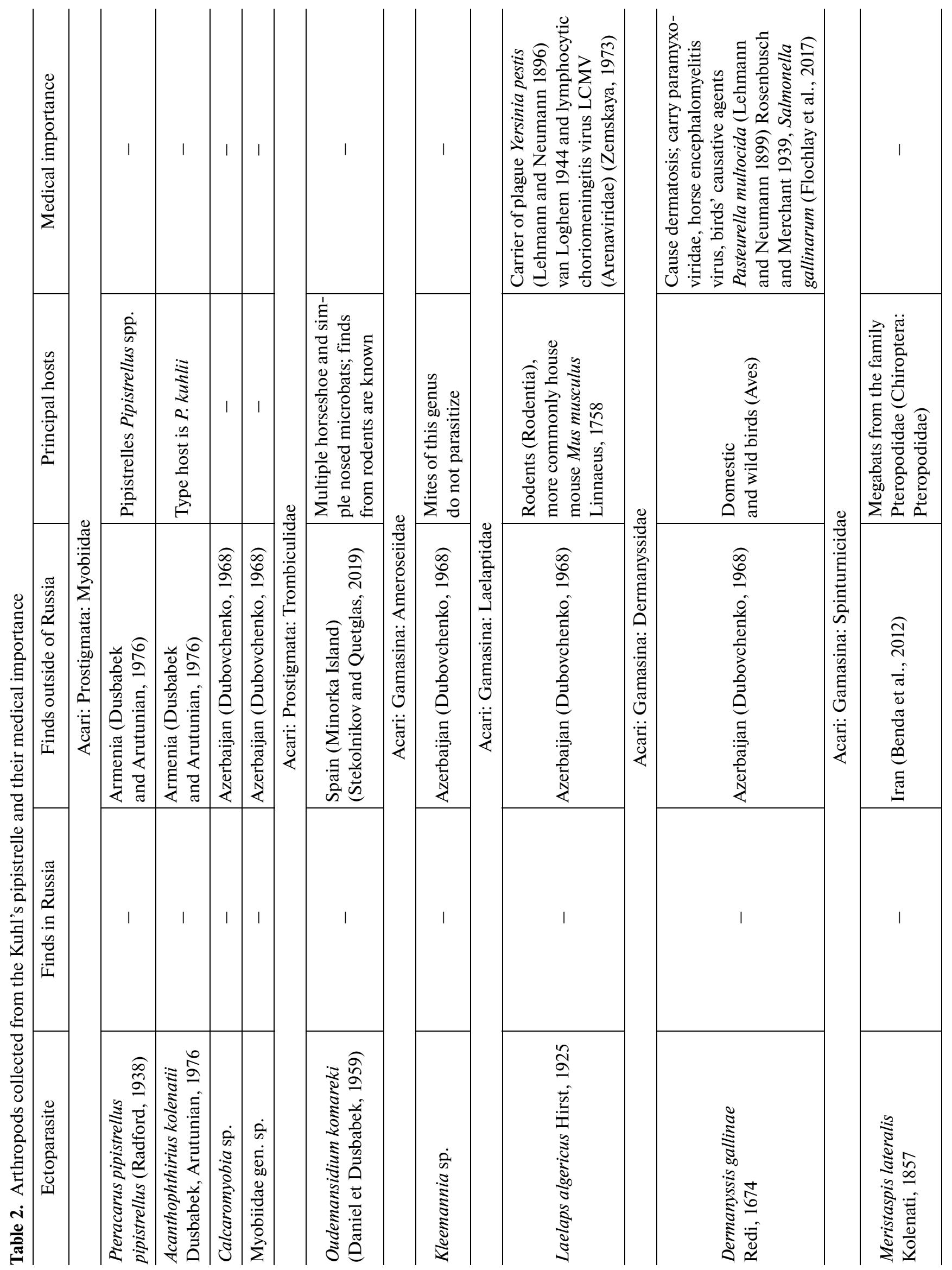

RUSSIAN JOURNAL OF BIOLOGICAL INVASIONS Vol. $11 \quad$ No. $4 \quad 2020$ 
ORLOVA et al.

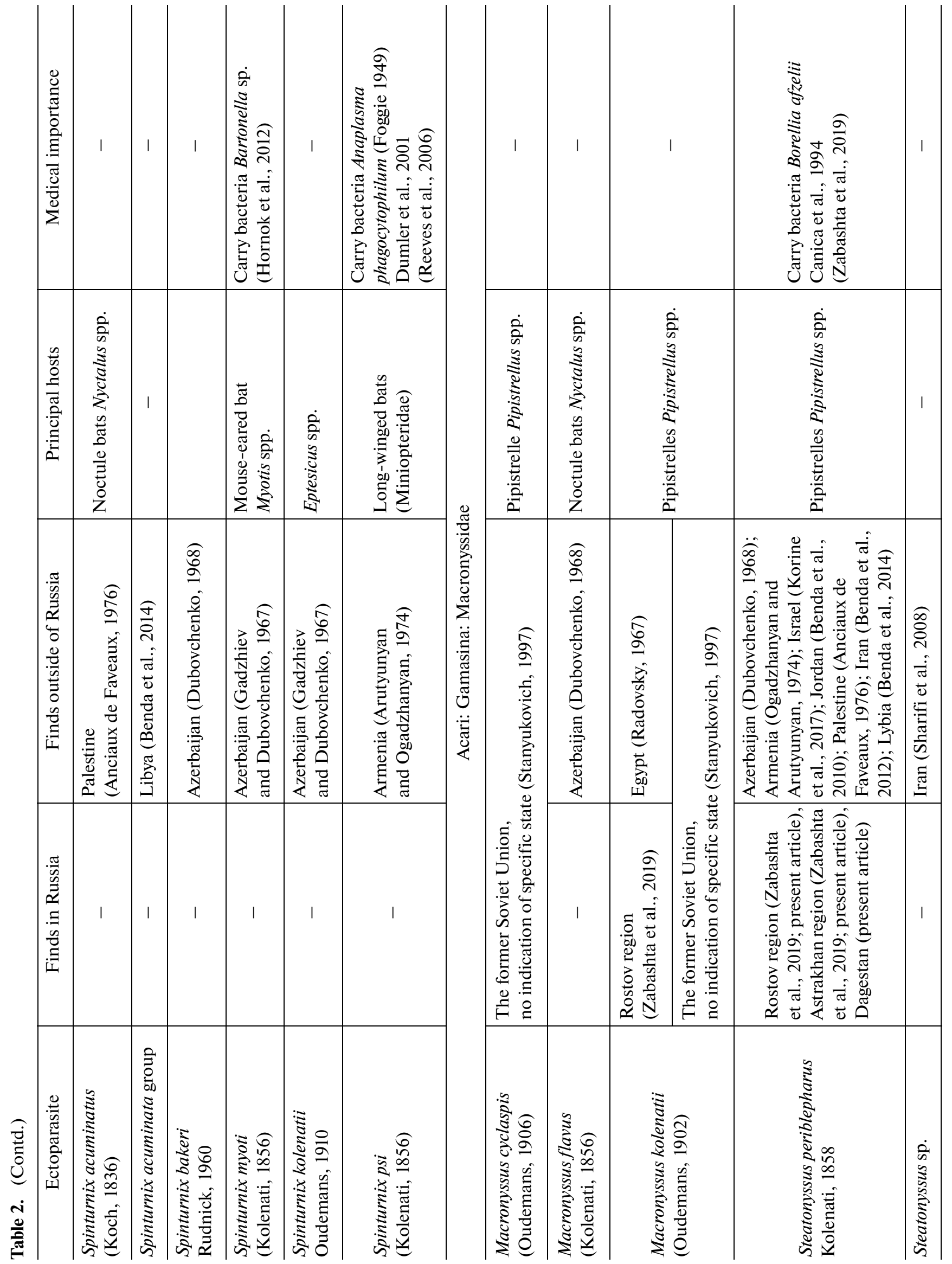

RUSSIAN JOURNAL OF BIOLOGICAL INVASIONS Vol. $11 \quad$ No. 42020 


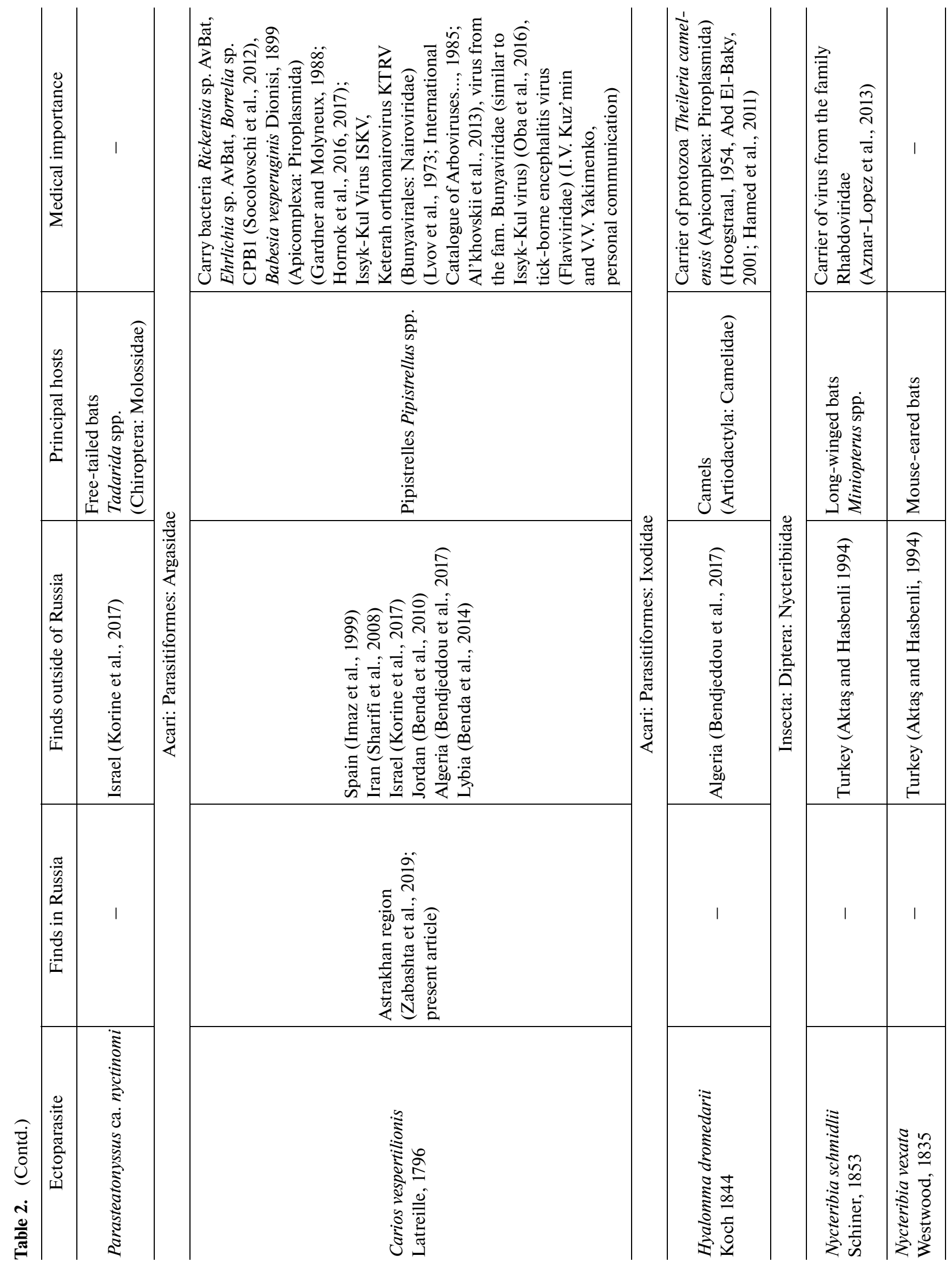




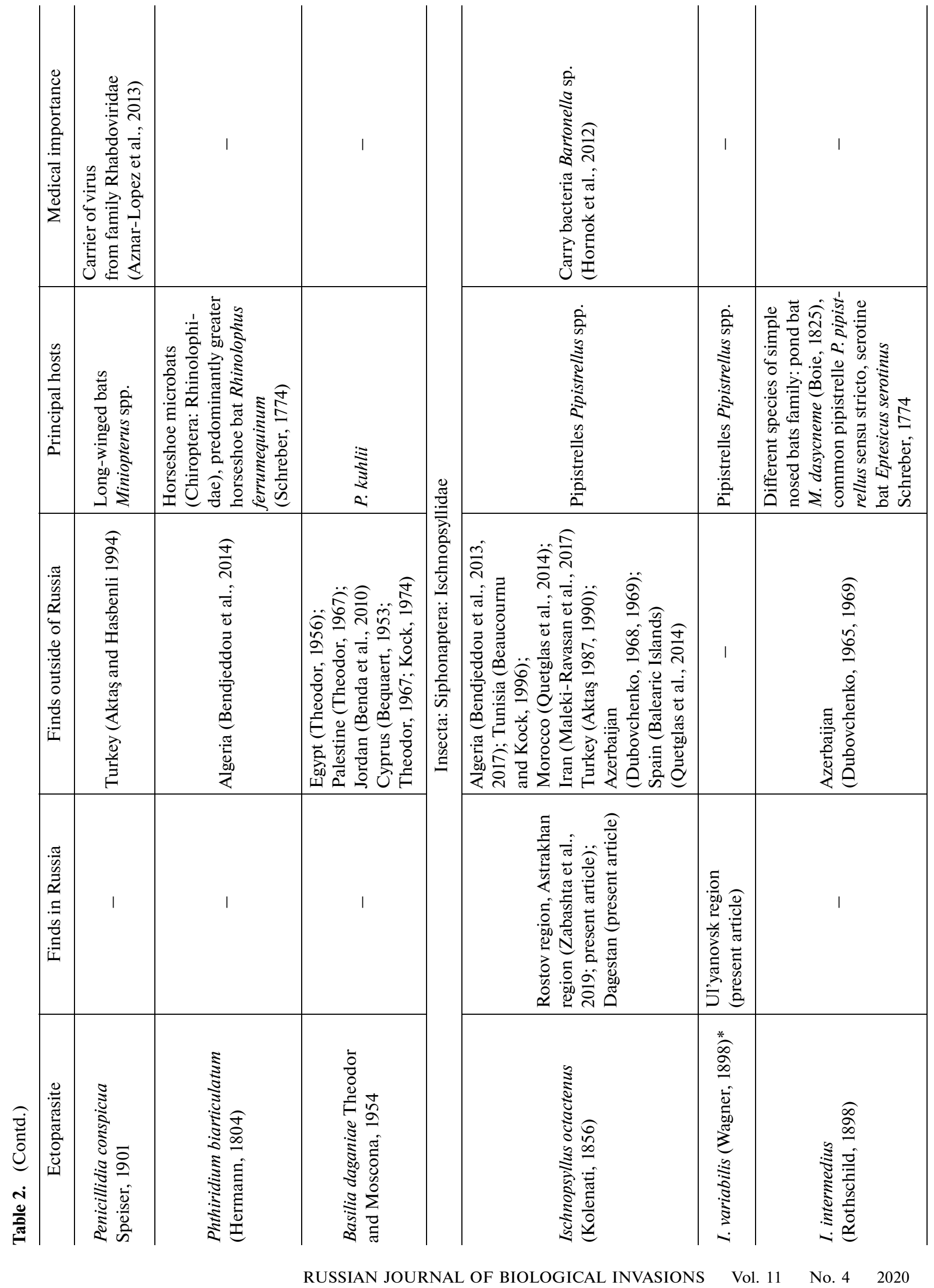




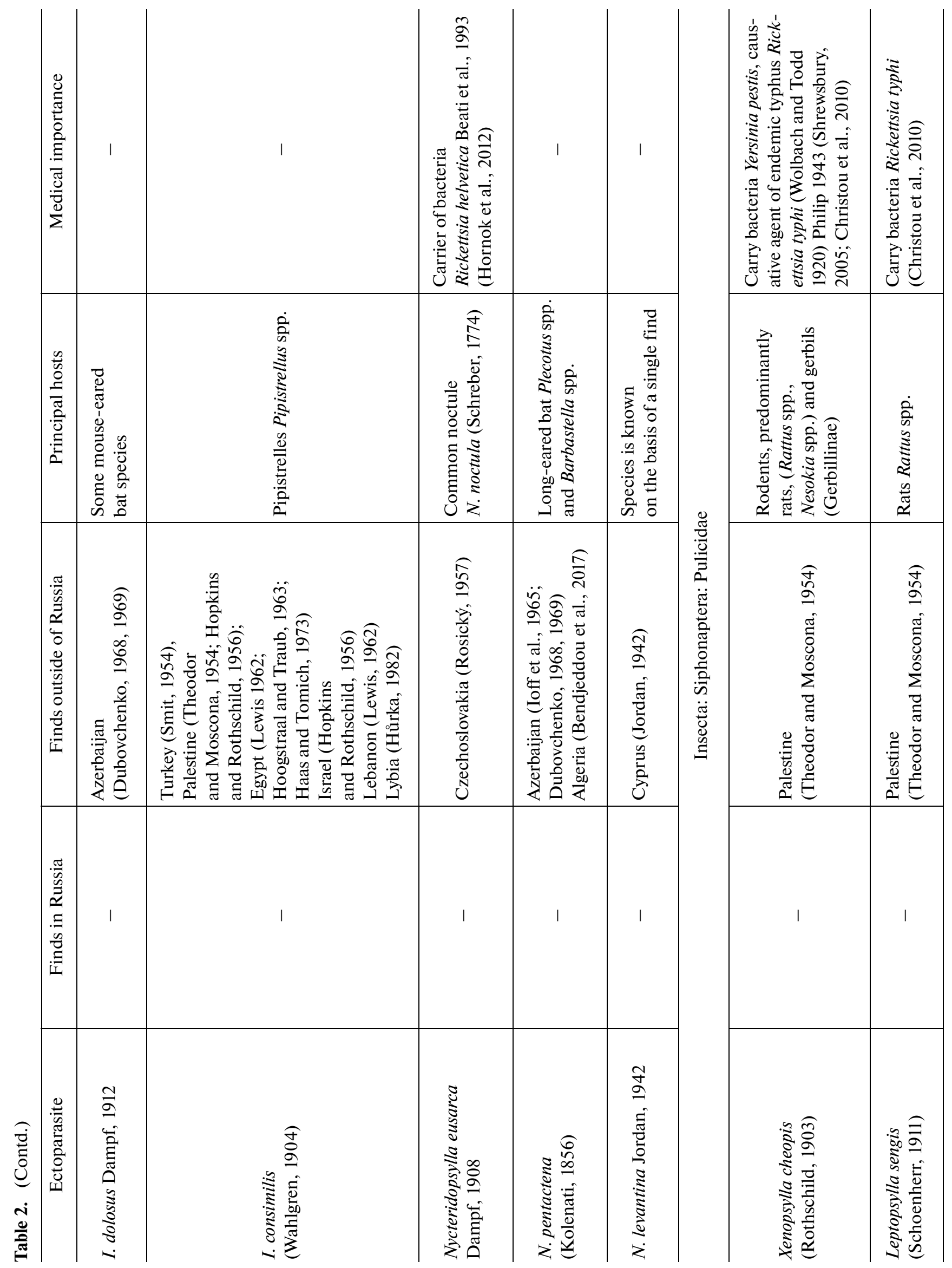




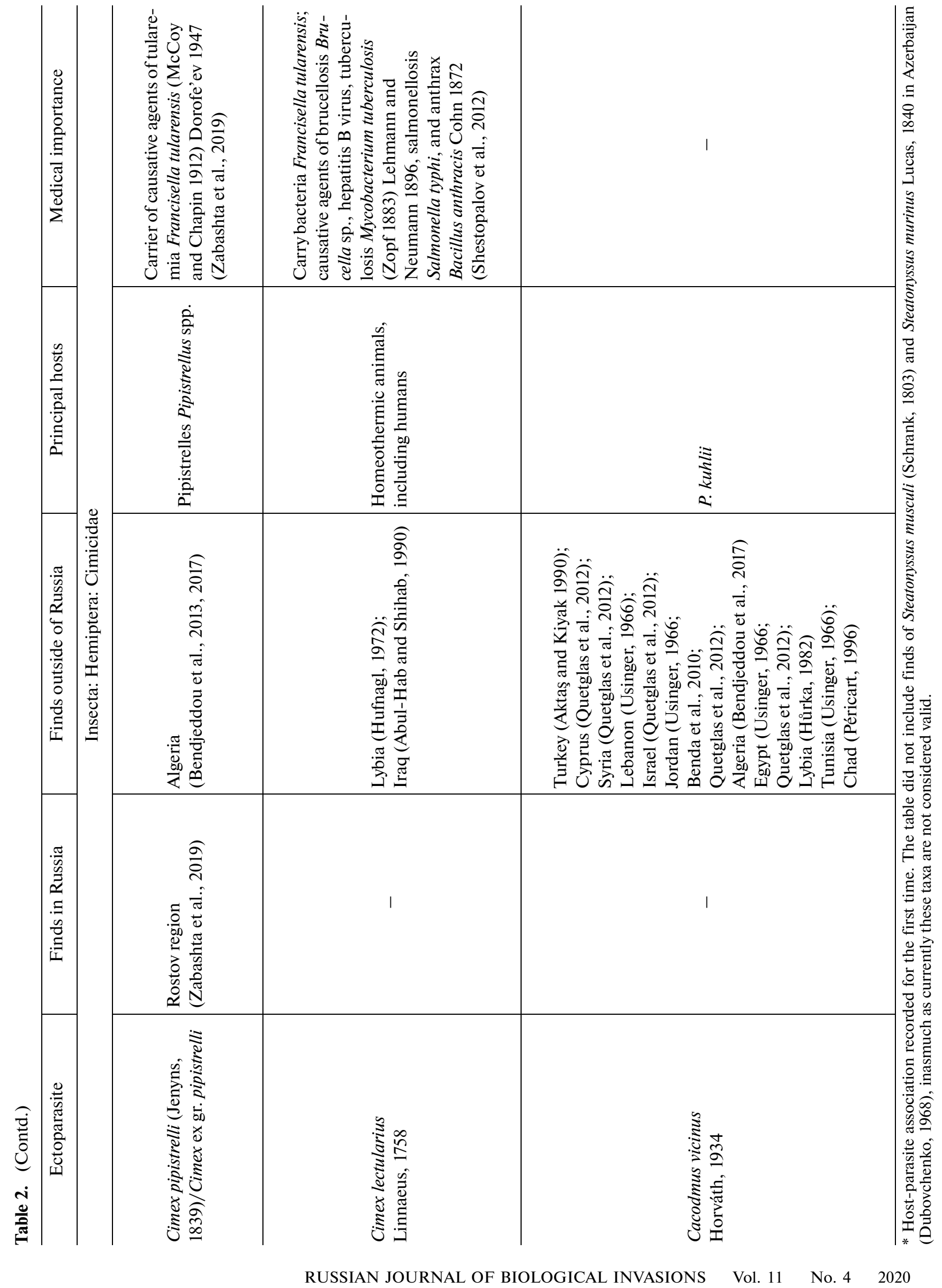


Table 3. Pathogens isolated from the Kuhl's pipistrelle

\begin{tabular}{|c|c|c|c|}
\hline Pathogen & Territory & Source & Diseases caused \\
\hline \multicolumn{4}{|c|}{ Apicomplexa: Eimeriidae } \\
\hline Eimeria pipistrellus & \multirow{3}{*}{ Saudi Arabia } & Alyousif et al., 1999 & \multirow{3}{*}{ Coccidiosis (eimeriosis) } \\
\hline Eimeria chiropteri & & Alyousif, 1999a & \\
\hline Eimeria kuhliensis & & Alyousif, 1999b & \\
\hline \multicolumn{4}{|c|}{ Bacteria: Spirochaetaceae } \\
\hline Borrelia sp. & \multirow{3}{*}{ Rostov region, Russia } & \multirow{3}{*}{ Zabashta et al., 2019} & \multirow{3}{*}{ Lyme disease } \\
\hline Borellia afzelii & & & \\
\hline Borrelia burgdorferi s. 1. genospecies Borrelia afzelii & & & \\
\hline \multicolumn{4}{|c|}{ Anaplasmataceae } \\
\hline Ehrlichia sp. & Rostov region, Russia & Zabashta et al., 2019 & Ehrlichiosis \\
\hline \multicolumn{4}{|c|}{ Francisellaceae } \\
\hline Francisella tularensis & Rostov region, Russia & Zabashta et al., 2019 & Tularemia \\
\hline \multicolumn{4}{|c|}{ Virus } \\
\hline Vaprio virus (VAPV) (Rhabdoviridae) & \multirow{2}{*}{ Italy } & Lelli et al., 2018 & - \\
\hline Toscana virus (TOSV) (Bunyaviridae) & & Verani et al., 1988 & - \\
\hline Alphacoronavirus (Coronaviridae) & $\begin{array}{l}\text { Italy, } \\
\text { Spain }\end{array}$ & $\begin{array}{l}\text { Lelli et al., } 2013 \\
\text { Falcón et al., } 2011\end{array}$ & \multirow[t]{2}{*}{-} \\
\hline Betacoronavirus (Coronaviridae) & Italy & Lelli et al., 2013 & \\
\hline Orthoreovirus (Reoviridae) & $\begin{array}{l}\text { Germany, } \\
\text { Italy }\end{array}$ & $\begin{array}{l}\text { Kohl et al., } 2012 \\
\text { Lelli et al., } 2012\end{array}$ & - \\
\hline
\end{tabular}

individuals ranges from 56 to $100 \%$. The next abundant species in our material flea I. octactenus is characterized by smaller infestation parameters (MI from 1 to $2, \mathrm{P}$ from 18 to $100 \%$ ). The remaining two species (tick $C$. vespertilionis and flea I. variabilis) are represented by isolated individuals.

Thus, according to our own and published data, 37 arthropods identified to species were recorded from the Kuhl's pipistrelle (mites, ticks, and insects), among which 36 are parasites (Table 2). In addition, 13 pathogenic microorganisms were isolated from this species over the past 20 years: three protozoan species (coccidia) of genus Eimeria, three groups of Borrelia (Borrelia burgdorferi s. 1., Borrelia afzelii, and Borrelia sp.), Ehrlichia sp., Francisella tularensis, and five viruses belonging to four families (Rhabdoviridae, Bunyaviridae, Coronaviridae, and Reoviridae) (Table 3).

In faunistic terms, arthropods are represented by Acari, including 16 species from eight families of three orders, and insects, including 18 species from four families of three orders.

Apparently, only some of the arthropod finds are due to parasitism. Thus, nonparasitic Kleemannia sp. appears to be an accidental find, because these mites are associated with bees. A number of finds are artifacts (mites Laelaps algericus, Dermanyssus gallinae,
Spinturnix psi, Meristaspis lateralis, Parasteatonyssus ca. nyctinomi, and Hyalomma dromedarii; bat flies Nycteribia schmidlii, Phthiridium biarticulatum, Penicillidia conspicua; fleas Xenopsylla cheopis and Leptopsylla sengis). At the same time, these finds, in particular, characterize active contacts of the Kuhl's pipistrelle with other bat species, as well as vertebrates from other classes (birds) and orders (primarily, domestic animals, such as rats and mice). In this case, the Kuhl's pipistrelle acts as a primary host (or one of these hosts) only for 11 species of ectoparasites (five Acari and six insect species), the most abundant and common among which (Acari St. periblepharus and C. vespertilionis, fleas I. octactenus and I. consimilis, bat flies B. daganiae, and bugs Cacodmus vicinus) appear to form a core of ectoparasitic P. kuhlii fauna.

Data on parasites of this species in Russia is on a smaller scale. As few as six arthropod species (three Acari and three insect species) and three taxa of pathogens were similarly recorded by us earlier, which can be attributed to insufficient knowledge about this host. Interestingly, all ectoparasitic species recorded in Russia are common to Pipistrellus spp. without being exclusively specific to $P$. kuhlii. As range of the bats expands northward, the core of their ectoparasitic fauna can be assumed to undergo a series of changes in 
that, in particular, highly host-specific species are lost. The latter include ectoparasitic insects typical to the Kuhl's pipistrelle, such as bat fly Basilia daganiae, flea Ischnopsyllus consimilis, and bug $C$. vicinus, the finds of which outside of the Mediterranean are unknown. All of the three listed species are transient ectoparasites sensitive, among other factors, to environmental parameters. Therefore, lack of the ecologically adequate conditions in their shelters and, primarily, not sufficiently high temperature can explain allocation (confinedness) of these insects to the ancestral range of P. kuhlii. In actual fact, outside of the Mediterranean, the core of ectoparasitic fauna of this host is represented only by pipistrelle genus-specific parasites (Acari St. periblepharus and C. vespertilionis and flea I. octactenus). Our finding from the Kuhl's pipistrelle of flea I. variabilis common to temperate belt of Europe, stretching from the Atlantic region to Urals, and not seen within the ancestral range of this host suggests that $P$. kuhlii can enter a spectrum of hosts of extrinsic parasites from allied bat species.

Of particular concern are the multiple finds (including accidental encounters) from the Kuhl's pipistrelle of bat flies, which are vectors of various diseases, such as $C$. vespertilionis, L. algericus, D. gallinae, $X$. cheopis, and Lept. sengis, as well as data with respect to the its isolated pathogens. Presumably, P. kuhlii is involved in transmission of a number of bacteria harmful to humans, e.g., Borrelia, Ehrlichia, and tularemia agent, and coronaviruses, for which a possibility of transmission to humans was confirmed by the 2020 pandemic (Table 3). Along with this, it has acquired a status of abundant species in some areas, after having become established in, e.g., many cities of European Russia. Additionally, as a bat, the Kuhl's pipistrelle is characterized by all traits common to this group, such as a capacity to cover long distances (can potentially spread pathogens over considerable area) and active use of anthropogenic structures for day roosts and hibernation roosts; in other words, it has contacts with humans and synanthropic species, including the ones involved in circulation of the natural focus infections, such as rats and house mice, and has the possibility to exchange pathogens. Altogether this determines urgency for the further in-depth inquiry into the ecology and medical importance of the Kuhl's pipistrelle and associated parasites in Russia.

\section{ACKNOWLEDGMENTS}

We thank the administration of the Astrakhan Nature Reserve and individually I.V. Sokolova, as well as the directorship and inspectors of the Dagestan State Nature Reserve and individually Deputy Director of Research G.S. Dzhamirzoev for their assistance in carrying out the work.

\section{FUNDING}

The study was performed within the framework of a state assignment of the Ministry of Science and Higher Education of the Russian Federation (project no. 0721-2020-0019).

\section{COMPLIANCE WITH ETHICAL STANDARDS}

Conflict of interest. The authors declare that they have no conflict of interest.

Statement on the welfare of animals. All experimental protocols were implemented in compliance with the guiding principles of the European Union for the care and use of animals (86/609/CEE) and in compliance with rules approved by the instruction of the Presidium of the USSR Academy of Sciences dated April 2, 1980, no. 12000-496, and the order of the Ministry of Higher Educational Institutions of the Soviet Union dated September 13, 1984, no. 22. Every effort was made to use the minimum number of animals necessary to obtain reliable scientific data.

\section{REFERENCES}

Abd El-Baky, S.M.M., Prevalence of external parasites in the south eastern desert of Egypt, J. Egypt. Soc. Parasitol., 2001, vol. 31, pp. 223-232.

Abul-Hab, J. and Shihab, B.A., Ectoparasites of some bats from Iraq, Bull. Iraq Nat. Hist. Mus., 1990, vol. 8, no. 2, pp. 59-64.

Aktaş, M. and Hasbenli, A., Bat flies of eastern Turkey (the east of Samsun-İskenderun line) (Diptera: Nycteribiidae), Gazi Univ. Fen Bilimleri Enstitusu Derg., 1994, no. 7, pp. 48-51.

Aktaş, M. and Kiyak, S., A new record of Cacodomus vicinus Horváth to the fauna of Turkey (Hemiptera: Cimicidae), Cent. Entomol. Stud. Ankara, Misc. Pap., 1990, no. 7, pp. 1-2.

Aktaş, M., Bat fleas of Eastern Turkey (the east of Samsunİskenderun line), Doğa - Turk. J. Zool., 1987, vol. 11, pp. 111-118.

Aktaş, M., Bat fleas of western Turkey (west of the line between Samsun and İskenderun), Doğa - Turk. J. Zool., 1990, vol. 14, pp. 107-112.

Al'khovskii, S.V., L'vov, D.K., Shchelkanov, M.Yu., Shchetinin, A.M., and Deryabin, P.G., Taxonomy of the Issyk-Kul virus (Issyk-Kul, ISKV; Bunyaviridae, Nairovirus), the causative agent of Issyk-Kul fever, isolated from bats (Vespertilionidae) and ticks Argas (Carios) vespertilionis Latreille, 1796, Vopr. Virusol., 2013, vol. 58, no. 5, pp. 11-15.

Alyousif, M.S., Al-Dakhil, M., and Al-Shawa, Y.R., Eimeria pipistrellus $\mathrm{n}$. sp. from Pipistrellus kuhlii (Chiroptera: Vespertilionidae) in Saudi Arabia, Korean J. Parasitol., 1999, vol. 37, no. 1, pp. 1-4.

Alyousif, M.S., Eimeria chiropteri n. sp. (Apicomplexa: Eimeriidae) from Saudi Arabian bat Pipistrellus kuhlii (Chiroptera: Vespertilionidae), J. Egypt. Soc. Parasitol., 1999a, vol. 29, no. 1, pp. 275-280.

Alyousif, M.S., Eimeria kuhliensis sp. n. (Apicomplexa: Eimeriidae) from pipistrelle bat, Pipistrellus kuhlii, Acta Protozool., 1999b, no. 38, pp. 313-316. 
Anciaux de Faveaux, M., Distribution des chiroptères en Algérie, avec notes écologiques et parasitologiques, Bull. Soc. Hist. Nat. Afr. Nord, 1976, vol. 67, pp. 69-80.

Ancillotto, L., Santini, L., Ranc, N., Maiorano, L., and Russo, D., Extraordinary range expansion in a common bat: The potential roles of climate change and urbanization, Sci. Nat., 2016, no. 103, p. 15.

Artaev, O.N and Smirnov, D.G., Bats (Chiroptera; Mammalia) of Mordovia: species composition and distribution features, Nat. Conserv. Res., Zapov. Nauka, 2016, vol. 1, no. 1, pp. 38-51.

Arutyunyan, E.S. and Ogadzhanyan, A.M., Parasitic mites of family Spinturnicidae Oudemans, 1901 (Parasitiformes, Gamasoidea) of Armenian bats, Biol. $\mathrm{Zh}$. Arm., 1974, vol. 27, no. 4, pp. 72-81.

Aznar-Lopez, C., Vazquez-Moron, S., Marston, D.A., Juste, J., Ibáñez, C., Berciano, J.M., Salsamendi, E., Aihartza, J., Banyard, A.C., McElhinney, L., Fooks, A.R., and Echevarria, J., Detection of rhabdovirus viral RNA in oropharyngeal swabs and ectoparasites of Spanish bats, J. Gen. Virol., 2013, vol. 94, pp. 69-75.

Balashov, Yu.S., Parazitizm kleshchei $i$ nasekomykh na nazemnykh pozvonochnykh (Parasitism of Mites and Insects on Terrestrial Vertebrates), St. Petersburg: Nauka, 2009.

Bauer, K., Ausbreitung der Weißrandfledermaus Pipistrellus kuhlii (Kuhl, 1819) in Osterreich, Mitt. Landesmus. Joan. Zool., 1996, no. 50, pp. 17-24.

Beaucournu, J.-C. and Kock, D., Notes on the Ischnopsyllinae of the African continent, III. Additions to the distribution of species (Insecta: Siphonaptera: Ischnopsyllidae), Senckenbergiana Biol., 1996, no. 75, pp. 163-169.

Benda, P., Faizolâhi, K., Andreas, M., Obuch, J., Reiter, A., Ševčík, M., Uhrin, M., Vallo, P., and Ashrafi, S., Bats (Mammalia: Chiroptera) of the Eastern Mediterranean and Middle East. Part 10. Bat fauna of Iran, Acta Soc. Zool. Bohemicae, 2012, vol. 76, nos. 3-4, pp. 163-582.

Benda, P., Lučan, R.K., Obuch, J., Reiter, A., Andreas, M., Backor, P., Bohnenstengel, T., Eid, E.K., Ševčík, M., Vallo, P., and Amr, Z.S., Bats (Mammalia: Chiroptera) of the Eastern Mediterranean and Middle East. Part 8. Bats of Jordan: fauna, ecology, echolocation, ectoparasites, Acta Soc. Zool. Bohemicae, 2010, vol. 74, pp. 185353.

Benda, P., Spitzenberger, F., Hanák, V., Andreas, M., Reiter, A., Ševčík, M., Šmíd, J., and Uhrin, M., Bats (Mammalia: Chiroptera) of the Eastern Mediterranean and Middle East. Part 11. On the bat fauna of Libya II, Acta Soc. Zool. Bohemicae, 2014, vol. 78, pp. 1-162.

Bendjeddou, M.L., Bitam, I., Abiadh, A., Bouslama, Z., and Amr, Z., New records of arthropod ectoparasites of bats from North-Eastern Algeria, Jordan J. Biol. Sci., 2013, vol. 6, no. 4, pp. 324-327.

Bendjeddou, M.L., Loumassine, H.A., Scheffler, I., Bouslama, Z., and Amr, Z., Bat ectoparasites (Nycteribiidae, Streblidae, Siphonaptera, Heteroptera, Mesostigmata, Argasidae, and Ixodidae) from Algeria, J. Vector Ecol., 2017, vol. 42, no. 1, pp. 13-23.

Bequaert, J.G., Exploration du Parc National Albert. Mission G.F. de Witte (1933-1935). Hippoboscidae and Nycteribiidae, Fasc. Inst. Parcs Nat., 1953, vol. 79, no. 7, pp. 89-94.
Bogdanowicz, W., Pipistrellus kuhlii (Kuhl, 1817) - Weissrandfledermaus, in Handbuch der Saugetiere Europas, vol. 4: Fledertiere, part II: Chiroptera II, Krapp, F., Ed., Wiebelsheim: Aula-Verlag, 2004, pp. 875-908.

Ceeluch, M. and Ševčík, M., First record of Pipistrellus kuhlii (Chiroptera) from Slovakia, Biologia (Bratislava), 2006, vol. 61, pp. 637-638.

Christou, C., Psaroulaki, A., Antoniou, M., Toumazos, P., Ioannou, I., Mazeris, A., Chochlakis, D., and Tselentis, Y., Rickettsia typhi and Rickettsia felis in Xenopsylla cheopis and Leptopsylla segnis parasitizing rats in Cyprus, Am. J. Trop. Med. Hyg., 2010, no. 83, pp. 13011304.

Danko, Š., Reprodukcia Hypsugo savii a Pipistrellus kuhlii na vychodnom Slovensku: Dal'šiedokazy o ichširenina sever, Vespertilio, 2007, no. 11, pp. 13-24.

Davygora, A.V., Il'in, V.Yu., Smirnov, D.G., and Shepelev, A.A., Modern eastern limits of distribution of Pipistrellus kuhlii in Russia, in Sovremennye problemy zoo- i filogeografii mlekopitayushchikh. Materialy konferentsii (Current Problems of Zoo- and Phylogeography of Mammals. Conference Proceedings), Pensa: Tov. Nauchn. Izd. KMK, 2009.

Demyanchik, V.V., Faunistic complexes of vertebrates in the settlements of Pripyat Polesie, in Ratsional'noe ispol'zovanie poimennykh zemel' (Rational Use of Floodplain Lands), Minsk, 2013, pp. 98-102.

Dubovchenko, T.A., Ectoparasites of Azerbaijan bats, Extended Abstract of Cand. Sci. (Biol.) Dissertation, Baku, 1968.

Dubovchenko, T.A., Materials for the study of fleas in bats in Azerbaijan, in Voprosy parazitologii AN Azerbaidzhanskoi SSR (Problems of Parasitology, Academy of Sciences of the Azerbaijan SSR), Baku: Elm, 1969, pp. 236-240.

Dubovchenko, T.A., New species of fleas for the fauna of Azerbaijan, Materialy nauchnoi sessii entomologov Azerbaidzhana (Proc. Sci. Session of Entomologists of Azerbaijan), Baku: Akad. Nauk Azerb. SSR, 1965, pp. 83-84.

Dusbabek, F. and Arutunian, E.S., Acanthophthirius kolenatii, a new species, and some new records of fur mites (Acarina: Myobiidae and Labidocarpidae) from Armenia, Folia Parasitol. (Prague), 1976, vol. 23, pp. 57-60.

Falcón, A., Vázquez-Morón, S., Casas, I., Aznar, C., Ruiz, G., Pozo, F., Perez-Breña, P., Juste, J., Ibáñez, C., Garin, I., et al., Detection of alpha and betacoronaviruses in multiple Iberian bat species, Arch. Virol., 2011, no. 156, pp. 1883-1890.

Feher, C.E., A feherszelü denever (Pipistrellus kuhli) erső magyarorszagy adatai, Deneverkutatas - Hung. Bat Res. News, 1995, no. 1, pp. 16-17.

Fiedler, W., Alder, H.U., and Wohland, P., Zweie neue nachweise der Weißrandfledermaus (Pipistrellus kuhli) für Deutschland, Z. Saugetierk, 1999, vol. 64, pp. 107109.

Filippova, N.A., Argasidae, in Fauna SSSR: Paukoobraznye (Fauna of the USSR: Arachnids), Moscow: Nauka, 1966, vol. 4, no. 4.

Flochlay, A.S., Thomas, E., and Sparagano, O., Poultry red mite (Dermanyssus gallinae) infestation: a broad impact parasitological disease that still remains a signifi- 
cant challenge for the egg-laying industry in Europe, Parasites Vectors, 2017, vol. 10, p. 357.

Gadzhiev, A.T. and Dubovchenko, T.A., Gamasid mites (Parasitiformes, Gamasoidea) of bats of Azerbaijan, Zool. Zh., 1967, vol. 46, no. 11, pp. 1716-1719.

Gardner, R.A. and Molyneux, D.H., Polychromophilus murinus: a malarial parasite of bats: life-history and ultrastructural studies, Parasitology, 1988, vol. 96, pp. 591-605.

Gashchak, S.P., Vlashchenko, A.S., and Naglov, A.V., Results of studying the fauna and radioactive contamination of bats in the Chornobyl exclusion zone in 20072009, Probl. Chornobil's'koï Zoni Vidchuzhennya, 2009, no. 9, pp. 102-124.

Gavris', G.G. and Kotserzhinskaya, I.M., The record of Pipistrellus kuhlii (Chiroptera, Vespertilionidae) on the northern border of the range in Ukraine (Shchorsky rayon, Chernihiv region), Vestn. Zool., 2002, vol. 36, no. 6, p. 50.

Godlevs'ka, L., Results of the work of the Kyiv Contact Center for Bats in 2012-2015, Pratsi Teriol. Shk., 2015, vol. 13 , pp. 11-19.

Godlevsky, L., Tyshchenko, V., and Negoda, V., First records of Pipistrellus kuhlii from Kyiv, Vestn. Zool., 2000, vol. 34, no. 3, p. 78 .

Haas, G.E. and Tomich, P.Q., The fleas (Siphonaptera) of Egypt. Early records from mammals, J. Egypt. Publ. Health Assoc., 1973, no. 48, pp. 1-17.

Haffner, M., Stutz, H.-P.B., and Zumsteg, M., First record of Swiss nursery colonies of Pipistrellus kuhli (Natterer in Kuhl, 1819) (Mammalia: Chiroptera) north of the Alps, Rev. Suisse Zool., 1991, vol. 98, pp. 702-703.

Hamed, M.I., Zaitoun, A.M.A., El-Allawy, T.A.A., and Mourad, M.I., Investigation of Theileria camelensis in camels infested by Hyalomma dromedarii ticks in Upper Egypt, J. Adv. Vet. Res., 2011, vol. 1, pp. 4-7.

Hoogstraal, H. and Traub, R., The fleas (Siphonaptera) of Egypt. Host-parasite relationships of lnsectivora and Chiroptera, J. Egypt. Publ. Health Assoc., 1963, vol. 38, pp. 111-130.

Hoogstraal, H., A preliminary, annotated list of ticks (Ixodoidea) of the Anglo-Egyptian Sudan, J. Parasitol., 1954, vol. 40, pp. 304-310.

Hopkins, G.H.E. and Rothschild, M., An Illustrated Catalogue of the Rothschild Collection of Fleas (Siphonaptera) in the British Museum (Natural History), vol. II: Coptopsyllidae, Vermipsyllidae, Stephanocircidae, Ischnopsyllidae, Hypsopthalmidae and Xiphiopsyllidae, London, 1956.

Hornok, S., Kovács, R., Meli, M.L., Gönczi, E., Hofmann-Lehmann, R., Kontschán, J., Gyuranecz, M., Dán, A., and Molnár, V., First detection of Bartonellae in a broad range of bat ectoparasites, Vet. Microbiol., 2012, vol. 159, nos. 3-4, pp. 541-543.

Hornok, S., Szőke, K., Görföl, T., Földvári, G., Tu, V.T., Takács, N., Jenő, K., Sándor, A.D., Estók, P., Epis, S., Boldogh, S.A., Kováts, D., and Wang, Y., Molecular investigations of the bat tick Argas vespertilionis (Ixodida: Argasidae) and Babesia vesperuginis (Apicomplexa: Piroplasmida) reflect "bat connection" between Central Europe and Central Asia, Exp. Appl. Acarol., 2017, vol. 72, pp. 69-77.

Hornok, S., Szőke, K., Kováts, D., Estók, P., Görföl, T., Boldogh, S.A., Takács, N., Jenő, K., Földvári, G., Barti, L., Corduneanu, A., and Sándor, A.D., DNA of piroplasms of ruminants and dogs in Ixodid bat ticks, PLoS One, 2016, vol. 11, no. 12.

Hufnagl, E., Libyan Mammals, Stoughton \& Harrow: The Oleander Press, 1972.

Hůrka, K., On the insect bat ectoparasites of coastal Libya (Cimicidae, Nycteribiidae, Streblidae, Ischnopsyllidae), Vestn. Cesk. Spol. Zool., 1982, vol. 46, pp. 85-91.

Il'in, V.Yu., Bystrakova, N.V., Dobrolyubov, A.N., Ermakov, O.A., Zolina, N.F., Kurmaeva, N.M., Luk'yanov, S.B., Pavlova, S.V., Smirnov, D.G., and Titov, S.V., Abstract of the mammalian fauna of Penza region, Izv. Penz. Gos. Pedagog. Univ. im. V. G. Belinskogo, 2006, vol. 1, no. 5, pp. 73-89.

Il'in, V.Yu., Dynamics of the ranges of three species of bats in the extreme southeast of Europe, Plecotus et al., 2000, no. 3, pp. 43-49.

Imaz, E., Aihartza, J.R., and Totorika, M.J., Ectoparasites on bats (Gamasida, Ixodida, Diptera) in Biscay (N Iberian peninsula), Misc. Zool., 1999, vol. 22, pp. 21-30.

International Catalogue of Arboviruses Including Certain Other Viruses of Vertebrates, Karabatsos, N., Ed., San Antonio, TX, Am. Soc. Trop. Med. Hyg., 1985.

Ioff, I.G., Mikulin, M.A., and Skalon, O.I., Opredelitel' blokh Srednei Azii i Kazakhstana (Keys to the Fleas of Central Asia and Kazakhstan), Moscow: Meditsina, 1965.

Jordan, K., On four new Paleartic bat-fleas in the British Museum collection, Eos (Madrid), 1942, vol. 18, pp. 243-250.

Kapitonov, V.I. and Grigor'ev, A.K., On the record of Kuhl's pipistrelle (Pipistrellus kuhlii) in Udmurtia, Tez. Dokl. 2-i Rossiiskoi univers. akademich. nauch. prakt. konf. (Reports of the 2nd Russian University Academic Scientific Practical Conf.), Izhevsk, 1995, part 2, pp. 40-41.

Kedrov, B.M. and Sheshurak, P.N., The first find of the Mediterranean bat Pipistrellus kuhlii (Chiroptera, Vespertilionidae) in Chernigov region (Ukraine), Vestn. Zool., 1999, vol. 33, no. 3, p. 66.

Kock, D., Pupipare Dipteren von Säugetieren des nordöstlichen Mittelmeerraumens (Ins.: Diptera), Senckenberg. Biol., 1974, vol. 17, pp. 87-104.

Kohl, C., Lesnik, R., Brinkmann, A., Ebinger, A., Radonić, A., Nitsche, A., Mühldorfer, K., Wibbelt, G., and Kurth, A., Isolation and characterization of three mammalian orthoreoviruses from European bats, PLoS One, 2012, vol. 7, no. 8, pp. 106-149.

Komarov, Yu.E. and Kuchiev, I.T., Distribution of summer colonies of some bats in Ossetia, in Ekol. gorn. mlekopitayushchikh: Inf. materialy (Ecology of Mountaneous Mammals: Information Materials), Sverdlovsk, 1982, pp. 56-57.

Korine, C., Pilosof, S., Gross, A., Morales-Malacara, J.B., and Krasnov, B.R., The effect of water contamination and host-related factors on ectoparasite load in an insectivorous bat, Parasitol. Res., 2017, vol. 116, no. 9, pp. 2517-2526.

Kuzyakin, A.P., Letuchie myshi (Bats), Moscow: Sov. Nauka, 1950.

Lada, G.A., The record of Kuhl's pipistrelle in Tambov region, Zool. Zh., 2010, vol. 89, no. 7, pp. 888-890.

Lelli, D., Moreno, A., Lavazza, A., Bresaola, M., Canelli, E., Boniotti, M.B., and Cordioli, P., Identification of mammalian orthoreovirus type 3 in Italian bats, Zoonoses Publ. Health, 2012, vol. 60, pp. 84-92. 
Lelli, D., Papetti, A., Sabelli, C., Rosti, E., Moreno, A., and Boniotti, M.B., Detection of coronaviruses in bats of various species in Italy, Viruses, 2013, vol. 5, pp. 2679-2689.

Lelli, D., Prosperi, A., Moreno, A., Chiapponi, C., Gibellini, A.M., De Benedictis, P., Leopardi, S., Sozzi, E., and Lavazza, A., Isolation of a novel Rhabdovirus from an insectivorous bat (Pipistrellus kuhlii) in Italy, Virol. J., 2018 , vol. 15 , no. 1 , p. 37.

Lewis, R.E., A preliminary list of the fleas of Lebanon, Proceedings of the Royal Entomological Society of London, Gen. Entomol., Ser. A, 1962, vol. 37, pp. 49-60.

Lindeman, G.V. and Subbotin, A.E., On the passage of bats in clay semideserts of the Trans-Volga region, Byull. MOIP, Otd. Biol., 1983, vol. 88, no.4, pp. 88-90.

Lvov, D.K., Karas, F.R., Timofeev, E.M., Tsyrkin, Y.M., Vargina, S.G., Veselovskaya, O.V., Osipova, N.Z., Grebenyuk, Y.I., Gromashevski, V.L., Steblyanko, S.N., and Fomina, K.B., "Issyk-Kul” virus, a new arbovirus isolated from bats and Argas (Carios) vespertilionis (Latr., 1802) in the Kirghiz S.S.R., Brief Rep., Arch. Ges. Virusforsch., 1973, vol. 42, no. 2, pp. 207-209.

Maleki-Ravasan, N., Solhjouy-Fard, S., Beaucournu, J.-C., Laudisoit, A., and Mostafavi, E., The fleas (Siphonaptera) in Iran: Diversity, host range, and medical importance, PLoS Neglected Trop. Dis., 2017, vol. 11, no. 1. https://www.ncbi.nlm.nih.gov/pmc/articles/ PMC5249249. Accessed August 3, 2020.

Meschede, A., Schlapp, G., and Weid, R., Erstfund einer Weißrandfledermaus (Pipistrellus kuhlii Kuhl, 1819) in Bayern, Nyctalus (N. F.), 1998, vol. 6, pp. 547-550.

Moratelli, R. and Calisher, C.H., Bats and zoonotic viruses: can we confidently link bats with emerging deadly viruses?, Mem. Inst. Oswaldo Cruz, 2015, vol. 110, no. 1, pp. 1-22.

Oba, M., Omatsu, T., Takano, A., Fujita, H., Sato, K., Nakamoto, A., Takahashi, M., Takada, N., Kawabata, H., Ando, S., and Mizutani, T., A novel Bunyavirus from the soft tick, Argas vespertilionis, in Japan, J. Vet. Med. Sci., 2016, vol. 78, no. 3, pp. 443-445.

Ogadzhanyan, A.M. and Arutyunyan, E.S., Ticks of the family Macronyssidae Oudemans, 1936 (Parasitiformes, Gamasoidea) parasitizing on bats of Armenia, Biol. Zh. Arm., 1974, vol. 27, no. 10, pp. 75-82.

Orlova, M.V. and Kononova, Yu.V., The causative agents of infectious diseases associated with specific ectoparasites of bats (Chiroptera) (review of literature data), Parazitologiya, 2018, vol. 52, no. 2, pp. 137-153.

Orlova, M.V., Stanyukovich, M.K., and Orlov, O.L., Gamasid Mites (Mesostigmata: Gamasina) Parasitizing Bats (Chiroptera: Rhinolophidae, Vespertilionidae, Molossidae) of Palaearctic Boreal Zone (Russia and Adjacent Countries), Tomsk: TSU Publ. House, 2016.

Péricart, J., Family Cimicidae Latreille, 1802-bed-bugs, in Catalogue of the Heteroptera of the Palearctic Region, Aukema, B. and Rieger, C., Eds., Amsterdam: Neth. Entomol. Soc., 1996, pp. 141-144.

Poluda, A. and Zagorodnyuk, I., Migrations of bats at the ornithological station "Lebedivka," in Migratsiinii status kazhaniv v Ukraïni (Migration Status of Bats in Ukraine), Kyiv, 2001, pp. 98-101.

Quetglas, J., Balvín, O., Lučan, R.K., and Benda, P., First records of the bat bug Cacodmus vicinus (Heteroptera:
Cimicidae) from Europe and further data on its distribution, Vespertilio, 2012, vol. 16, pp. 243-248.

Quetglas, J., Nogueras, J., Ibáñez, C., and Beaucournu, J.-C., Presencia en la Península Ibérica de una pulga africana de murciélagos: Rhinolophopsylla unipectinata arabs (Siphonaptera: Ischnopsyllidae) y otras nuevas citas de pulgas de murciélagos para España y Marruecos, Galemys, 2014, vol. 26, pp. 41-47.

Racey, P.A., Reproductive assessment of bats, in Ecological and Behavioural Methods for the Study of Bats, Kunz, T.H. and Parsons, S., Eds., Baltimore: Johns Hopkins Univ. Press, 2009, pp. 249-264.

Radovsky, F., The Macronyssidae and Laelapidae (Acarina: Mesostigmata) Parasitic on Bats, Berkeley: Univ. Ca., 1967.

Reeves, W.K., Dowling, A.P., and Dasch, G.A., Rickettsial agents from parasitic Dermanyssoidea (Acari: Mesostigmata), Exp. Appl. Acarol., 2006, vol. 38, nos. 2-3, pp. 181-188.

Reiter, A., Benda, P., and Hotovy, J., First record of the Kuhl's pipistrelle, Pipistrellus kuhlii (Kuhl, 1817), in the Czech Republic, Lynx, 2007, vol. 38, pp. 47-54.

Rosický, B., Blechy - Aphaniptera, in Fauna ČSR, Praha: Nakladatelství Česk. Akad. Věd, 1957, vol. 10.

Sachnowicz, K., Piskorski, M., and Tereba, A., Systematics and taxonomy of Pipistrellus kuhlii (Kuhl, 1817) in central Europe and the Balkans, Zootaxa, 2017, vol. 4306, no. 1 , pp. 53-66.

Sachnowicz, K., Wower, F., and Bashta, A.-T., Further range extension of Pipistrellus kuhlii (Kuhl, 1817) in central and eastern Europe, Acta Chiropterol., 2006, vol. 8, no. 2, pp. 543-548.

Schountz, T., Virology and immunology of bats, in Bat Evolution, Ecology, and Conservation, Adams, R.A. and Pedersen, S.C., Eds., New York: Springer Sci., 2013, pp. 393-412.

Shaimardanov, R.T., New records (1985-1993) of species of bats (Chiroptera) that are rare and little known for the fauna of Kazakhstan, Plecotus et al., 2001, no. 4, pp. $82-83$.

Sharifi, M., Mozafari, F., Taghinezhad, N., and Javanbakht, H., Variation in ectoparasite load reflects life historytraits in the lesser mouse-eared bat Myotis blythii (Chiroptera: Vespertilionidae) in western Iran, J. Parasitol., 2008, vol. 94, no. 3, pp. 622-625.

Shepelev, A.A., Il'in, V.Yu., and Smirnov, D.G., Rare species of bats in Penza and its environs, in Bioraznoobrazie: problemy i perspektivy sokhraneniya. Materialy mezhdunarodnoi nauchnoi konferentsii, posvyashchennoi 135-letiyu so dnya rozhdeniya I.I. Sprygina (Biodiversity: Problems and Prospects for Conservation. Proc. Int. Sci. Conf. Dedicated to the 135th Anniversary of the Birth of I.I. Sprygin), Pensa, 2008, part 2, pp. 304-305.

Shestopalov, N.V., Roslavtseva, S.A., Alekseev, M.A., Eremina, O.Yu., Tsarenko, V.A., and Osipova, N.Z., Epidemiological significance of bed bugs and measures to combat them. Information letter, Dezinfektsionnoe Delo, 2012, vol. 81, no. 3, pp. 42-46.

Shpak, A. and Larchenko, A., Range expansion of Kuhl's pipistrelle (Pipistrellus kuhlii) into Belarus, Proc. Theriol. Sch., 2016, vol. 14, pp. 99-102.

Shrewsbury, J.F.D., A History of Bubonic Plague in the British Isles, Cambridge: Cambridge Univ. Press, 2005. 
Sitnikova, E.F., Kruskop, S.V., and Mishta, A.V., Materials on the bats fauna of Bryansk region, Plecotus et al., 2009, nos. $11-12$, pp. 32-49.

Smirnov, D.G. and Vekhnik, V.P., On the current distribution of Pipistrellus kuhlii (Chiroptera: Vespertilionidae) in the Volga region, Povolzh. Ekol. Zh., 2011, no. 2, pp. 193-202.

Smirnov, D.G., Vekhnik, V.P., Kurmaeva, N.M., and Shepelev, A.A., New information on the distribution of Pipistrellus kuhlii in the Volga region, Teriofauna Rossii $i$ sopredel'nykh territorii (VIII s"ezd VTO). Materialy mezhdunarodnogo soveshchaniya (Theriofauna of Russia and Adjacent Territories (VIII Congress of the AllRussian Theriological Society). Materials of the International Meeting), Moscow, 2007, p. 463.

Smit, F.G.A.M., New bat-fleas (Siphonaptera: Ischnopsyllidae), Parasitology, 1954, vol. 44, pp. 144-156.

Socolovschi, C., et al., Borrelia, Rickettsia, and Ehrlichia species in bat ticks, France, 2010, Emerging Infect. Dis., 2012, vol. 18, no. 12, pp. 1966-1975.

Spitzenberger, F. and Bauer, K., Weißrandfledermaus Pipistrellus kuhlii (Kuhl, 1817), in Die Säugetierfauna Österreichs. Bundesministerium für Land-und Forstwirtschaft Umwelt und Wasserwirtschaft, Spitzenberger, F., Ed., Graz, 2001, pp. 245-248.

Stanyukovich, M.K., Keys to the gamasid mites (Acari: Parasitiformes, Mesostigmata, Macronyssoidea et Laelaptoidea) parasiting bats (Mammalia, Chiroptera) from Russia and adjacent countries, Rudolstädter Naturhist. Schr., 1997, vol. 7, pp. 13-46.

Stekolnikov, A.A. and Quetglas, J., Bat-infesting chiggers (Acariformes: Trombiculidae) of the Balearic Islands and new data on the genus Trisetica Traub et Evans, 1950, Folia Parasitol., 2019, vol. 66.

Strelkov, P.P. and Il'in, V.Yu., Bats (Chiroptera, Vespertilionidae) in the south of the Middle and Lower Volga regions, Tr. Zool. Inst. Akad. Nauk SSSR, 1990, vol. 225, pp. 42-167.

Strelkov, P.P., Expansion of ranges by Palaearctic bats (Chiroptera, Mammalia) as an example of invasion in anthropogenic biotopes, in Biologicheskie invazii v vodnykh i nazemnykh ekosistemakh (Biological Invasions in Aquatic and Terrestrial Ecosystems), Moscow: Tov. Nauchn. Izd. KMK, 2004, pp. 202-207.

Strelkov, P.P., Order Chiroptera, Bats, in Mlekopitayushchie Fauny SSSR. Ch. 1 (Mammals of the Fauna of the USSR. Part 1), 1963, pp. 134-218.

Strelkov, P.P., Unkurova, V.I., and Medvedeva, G.A., New data on Kuhl's pipistrelle (Pipistrellus kuhlii) and dynamics of its range in the USSR, Zool. Zh., 1985, vol. 64 , no. 1 , pp. 87-97.

Theodor, O. and Moscona, A., On bat parasites in Palestine. I. Nycteribiidae, Streblidae, Hemiptera, Siphonaptera, Parasitology, 1954, vol. 44, pp. 157-245.

Theodor, O., An Illustrated Catalogue of the Rothschild Collection of Nycteribiidae in the British Museum (Natural History), with Keys and Short Descriptions for the Identification of Subfamilies, Genera, Species and Subspecies, London: Br. Mus. (Nat. Hist.) Publ., 1967.
Theodor, O., On the genus Tripselia and the group of Basilia bathybothyra (Nycteribiidae, Diptera), Parasitology, 1956, vol. 46, nos 3-4, pp. 353-394.

Usinger, R.L., Monograph of Cimicidae, Washington, DC: Entomol. Soc. Am., 1966.

Verani, P., Ciufolini, M.G., Caciolli, S., Renzi, A., Nicoletti, L., Sabatinelli, G., Bartolozzi, D., Volpi, G., Amaducci, L., and Coluzzi, M., Ecology of viruses isolated from sand flies in italy and characterized of a new Phlebovirus (Arabia virus), Am. J. Trop. Med. Hyg., 1988, vol. 38, pp. 433-439.

Vereshchagin, N.K., Mlekopitayushchie Kavkaza (Mammals of the Caucasus), Moscow: Akad. Nauk SSSR, 1959.

Vernier, E. and Bogdanowicz, W., Pipistrellus kuhlii (Kuhl, 1817), in The Atlas of European Mammals, MitchellJones, A.J., Amori, G., Bogdanowicz, W., Krystufek, B., Reinjders, P.J.H., Spitzenberger, F., Stubbe, M., Thissen, J.B.M., Vohralik, V., and Zima, J., Eds., London: Acad. Press, 1999, pp. 120-121.

Whitaker, Jr., J.O., Collecting and preserving ectoparasites for ecological study, in Ecological and Behavioral Methods for the Study of Bats, Washington: Smithsonian Inst. Press, 1988, pp. 459-474.

Yarmysh, N.N. and Kazakov, B.A., Records of rare species in the Ciscaucasia, in Redkie vidy mlekopitayushchikh i ikh okhrana: Materialy II Vsesoyuz. soveshch. (Rare Species of Mammals and Their Protection: Proc. II All-Union Meeting), Moscow: Nauka, 1977, pp. 65-66.

Yarmysh, N.N., Kazakov, B.A., Sonina, I.Yu., and Usvaiskaya, A.Kh., New records of bats in the North Caucasus, in Rukokrylye (Chiroptera) (Bats. (Chiroptera)), Moscow: Nauka, 1980, pp. 72-77.

Zabashta, M.V., Orlova, M.V., Pichurina, N.L., Khametova, A.P., Romanova, L.V., Borodina, T.N., and Zabashta, A.V., Participation of bats (Chiroptera, Mammalia) and their ectoparasites in the circulation of pathogens of natural focal infections in southern Russia, Parazitologiya, 2019, vol. 53, no. 1, pp. 3-13.

Zagorodnyuk, I.V. and Reznik, O.S., Expansion of the dark-headed form into the range of Garrulus glandarius in Donbass, Berkut, 2007, vol. 16, no. 1, pp. 103-109.

Zav'yalov, E.V. and Shlyakhtin, G.V., Dynamics of the northern border of the range of the Mediterranean bat in the European part of Russia, in Tez. dokl. VI s"ezda Teriologicheskogo ob-va v In-te problem ekologii i evolyutsii im. A.N. Severtsova RAN (Reports of the VI Congress of the Teriological Society in Severtsov Institute of Problems of Ecology and Evolution, Russian Academy of Sciences), Moscow, 1999, p. 92.

Zemskaya, A.A., Paraziticheskie gamazovye kleshchi i ikh meditsinskoe znachenie (Parasitic Gamasid Mites and Their Medical Significance), Moscow: Meditsina, 1973.

Zolina, N.F., Shepelev, A.A., Smirnov, D.G., and Shepelev, A.A., Preliminary information about bats in Penza and its environs, Povolzh. Ekol. Zh., 2007, no. 2, pp. 116-127.

Translated by E. Kuznetsova 